\title{
Cooperate governance and financial performance in War Child Uganda
}

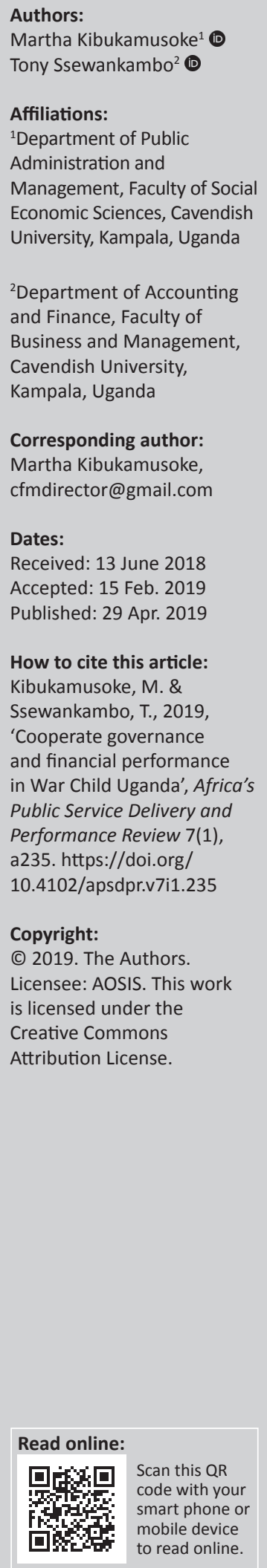

Background: The corporate governance structure has employed a number of multiple empirical techniques that have influenced many organisations worldwide. War Child in Uganda, an independent international organisation, faced a number of financial data alterations, whose major cause was not following budgets and not adhering to rules and regulations on the use of finances. The failure to disclose information on the proper earnings caused a lot of irregularities in the financial performance of the organisation.

Aim: This study aimed at investigating the effect of cooperate governance on financial performance of War Child in Uganda as guided by the following objectives: (1) to find out if the staff of War Child are aware of the existence of financial systems that lead to financial performance in War Child in Uganda and (2) to find out the relationship between corporate governance and financial performance in War Child in Uganda.

Methods: The study adopted cross-sectional and descriptive research designs where both qualitative and quantitative approaches were used.

Results: The findings of the study showed that the employees of War Child Uganda are aware of the existence of financial systems; however, the failure in financial performance is not explained. The findings also showed that there is a positive relationship between corporate governance and financial performance of War Child in Uganda.

Conclusion: Recommendations further state that if War Child in Uganda embraces more accountability, transparency and competence as a way of improving its financial performance, there will be a significant improvement in financial accountability, reporting, budget performance and liquidity.

Keywords: Corporate governance; financial systems; financial performance; financial accountability; transparency.

\section{Introduction and background}

The term non-governmental organisation (NGO) is used to define an agency that has no government control but receives aid and donations from national and international agencies to carry out poverty alleviation activities on humanitarian sectors (Perkins \& Hendry 2015). Non-governmental organisations in Uganda are governed by the NGO Registration Act 1989 that was amended in 2006. The National Board of NGO is authorised under the current legal framework to oversee all NGO activities in the country. Despite their importance in Uganda, NGOs face challenges from regulating agencies, laws and policies governing their regulations, as well as internal NGO challenges. The Ugandan government is now considering relying more on the NGO sector for a variety of welfare and development objectives. In particular, the Ugandan government considered subcontracting the delivery of certain services to NGOs which can be used as a medium to receive public funding to accomplish various tasks. The study, thus, investigates the effect of cooperate governance on the financial performance of War Child Uganda, where the background, problem statement, objectives, literature review, methodology and findings of the study are discussed.

Corporate governance is a system of values, policies and institutions that a society uses to manage its economic, political and social affairs through interactions within the state, civil society and the private sector (Potucek et al. 2005). Corporate governance operates at every level of human enterprise and gives an oversight on the management of firms through strategic planning and risk management, oversight of regulatory compliance, independent monitoring of audit functions, economic sustainability and corporate responses to market changes. It is assumed that through corporate governance, financial performance can be effectively realised in organisations (Zouari \& Taktak 2014). 
Financial performance is a subjective measure of how well an organisation uses its assets to generate revenue (Robinson 2003). Kaplan (2004) and Hayes et al. (2005) suggested that the use of competitive priorities is one of the ways an organisation can use to improve financial performance. In addition, Kakuru (2000a and 2000b) also asserts that the competitive advantage of an organisation is a means through which financial performance is used to improve organisations. Kakuru further states that a competitive advantage is also realised through the perspectives of liquidity, budgeting, accountability and reporting. For this to happen, an organisation should have qualified personnel in the field of accounting and finance whose role is confined to compiling accounts and managing the cost accounting and financial management systems.

A financial system can be defined as a set of official institutions and arrangements that govern payments between nations and exchange rates amongst currencies, 'the glue that binds national economies together' (Eichengreen \& Rose 1999). The financial system is also known as the processes and procedures used by an organisation's management to exercise financial control and accountability. A financial system can also be looked at as a methodology that organisations use to oversee and govern their income, expenses and assets. It also aims at maximising profits and ensuring sustainability. It is important to note that the war child organisations are non-profit-making organisations whose financial systems aim at ensuring sustainability of projects so as to ensure financial performance at the end of it all. What is a financial system, and what does the term 'financial systems' refer to? The answer to this question is not obvious (Schmidt \& Tyrel 2004). We look at how an organisation accumulates wealth and transfers the income over time. What options are available and how are they used? How do they obtain finances and how do they cope with the risks?

War Child is part of an international network of independent organisations, such as War Child Holland (WCH), War Child Canada (WCC) and War Child UK (WCUK), which have similar objectives and joint activities but different roles. War Child Uganda has been in Uganda since 2004, with a mission of 'no child should ever be part of war'. The organisation has management practices, sets of internal procedures and informal guidelines that govern how its corporate officials make decisions on who bears responsibility in the case of losses or injuries that come up from such decisions. Numerous global corporate accounting scandals that assumed nearepidemic proportion in recent years have therefore informed this study. Notable cases include the Enron scandal in the USA, a company that reached dramatic heights only to face a dizzying fall and was declared bankrupt in December 2001 (Michaely 2018). In South Africa, cases of accounting scandals have been recorded in Randgold \& Exploration Company (Iyang 2009). In Nigeria, the Managing Director and Chief Financial Officer of Cadbury Nigeria Plc were dismissed in 2006 for inflating the profits of a company for a number of years before the company's foreign partner acquired full control (Alo 2003; Sasuni 2003; Wilson 2006).

In Uganda, factors responsible for poor corporate performance, especially in banks, emanate from the lack of transparency, accountability and poor ethical conduct (Kibirango 1999). Commercial banks' failures have been linked to self-inflicted causes resulting from bank owners, such as International Credit Bank (ICB), Greenland Bank (GBL) and Coop Bank. These banks were afflicted with the one-man management syndrome of corporate governance, where Thomas Kato represented ICB, Suleiman Kiggundu represented GBL and the United States Agency for International Development (USAID) represented cooperative bank.

The way in which accountability is addressed in War Child Uganda could be a problem. Accountability may not necessarily enable international NGOs to achieve their missions to alleviate poverty and eliminate injustice. It is argued that if these organisations have to achieve their missions, this will require more strategic forms of accountability geared towards fundamentally changing those social economic and political structures that promote poverty. There is a need for a conceptual framework that enables international NGOs to work their mission and values into policies and practice (Cavil \& Sohail 2007). Poor ethical conduct destroys management of financial performance and corporate governance in War Child Uganda. The lack of transparency in management also causes great harm (Wanyama 2006).

The general objective of the study was to find out the effect of corporate governance on the financial performance in War Child in Uganda. The study was based on the following objectives:

- to find out if the staff of War Child are aware of the existence of financial systems that lead to financial performance in War Child in Uganda

- to find out the relationship between corporate governance and financial performance in War Child in Uganda.

This study was carried out with the aim of making an academic contribution in the area of cooperate governance, financial systems and financial performance. The study findings can be used to help enhance NGOs' capacity to build mechanisms for increasing the quality of financial performance. The findings can also be used to generate policies for the donors on how they can improve ways through which NGOs can fully comply with donor requirements. This can eventually guide donors to identify what kind of technical support they should provide to the NGOs before giving them any funding.

This article is organised as follows. It first discusses the problem statement, followed by the conceptual framework, description of the model and objectives of the study. Then the article highlights the literature review, explains the methodology and presents the findings of the study as 
per the objectives. Recommendations of the study are then explained and lastly the conclusion of the study is presented.

\section{Problem statement}

BVL \& Company Certified Public Accountants (2010) indicated that the financial reports produced by $\mathrm{WCH}$ did not meet the quality standard set by the donors. These reports were required to meet the accounting standard which is prepared using the generally accepted accounting practices (cash basis accounting). As evidenced by Wanyama (2006), there is a gap between corporate governance and financial performance in War Child Uganda, which caused it to experience persistent annual non-financial accountabilities. The non-financial accountabilities were from organisations that had been sub-granted to carry out activities for JanuaryDecember 2010 that should have been submitted by the end of the year. However, by that date the War Child 2010 annual report stated that $55.14 \%$ of the pre-planned flows of financial data were altered as year-end transactions, implying a weaker liquidity position for the entity.

This has since led to financial data alterations that were identified through the existence of poor financial performance, budgets not followed, and rules and regulations on the use of finances not being adhered to, thus unable to account for such massive funds. The financial information is deliberately and artificially smoothed, as well as inadequate. Misleading earnings are disclosed, such as shifting revenue or expense items between periods, depending on the objectives to be achieved, besides having sets of internal procedures and informal guidelines to govern how its corporate officials make decisions on who bears responsibility on losses or injuries that arise from such decisions. These shortcomings are what guide the study to aim at providing pointers for improving the performance of NGOs that may face such similar problems.

\section{Conceptual framework}

A conceptual framework is a set of broad ideas and principles taken from relevant fields of enquiry and used to structure a subsequent presentation (Kombo \& Tromp 2009). It forms part of the agenda for negotiation to be scrutinised, tested, reviewed and reformed as a result of investigation and it explains the possible connections between the variables (Smyth 2004).

A conceptual framework for the study shows the relationship between corporate governance and financial performance of NGOs in War Child Uganda (see Figure 1).

\section{Description of the model}

Corporate governance was operationalised using an instrument developed by Gavin and Geoffrey (2004) and is measured by the following parameters: conduct, role clarity, competency, transparency and accountability. The concept of information inductance was operationalised from the

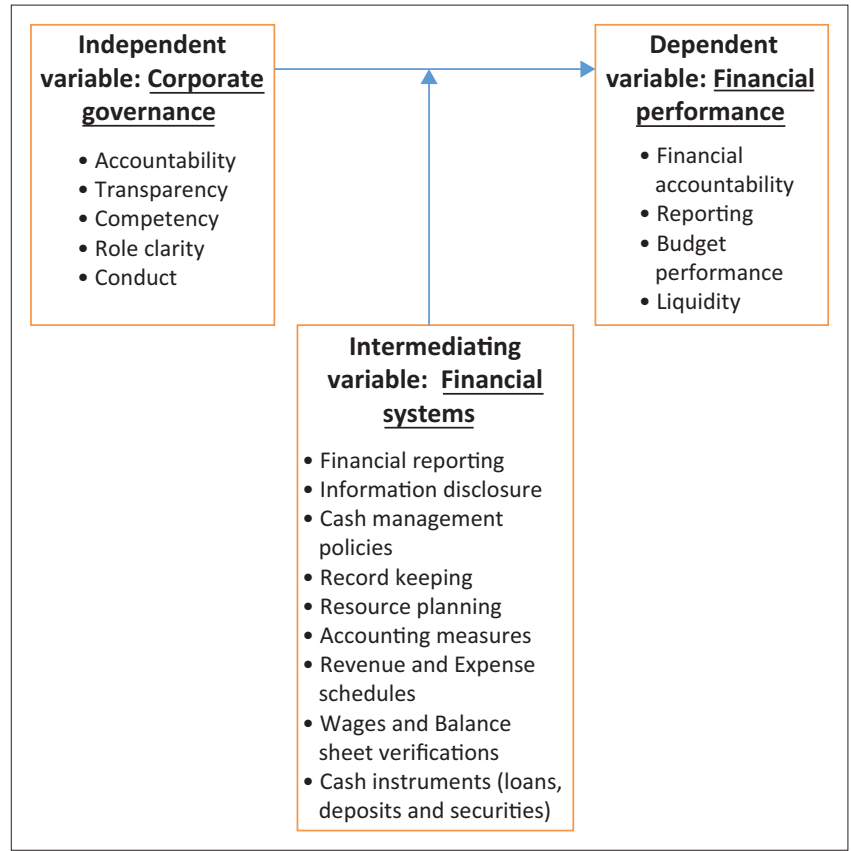

Source: Adopted from Schmidt, R.H. \& Tyrell, M., 2003, 'Financial systems, corporate finance and corporate governance', European Financial Management Source 3(3), 333-361. https://doi.org/10.1111/1468-036X.00047; Birnberg, J.G., \& Heiman-HoVman, V., 1993, 'Accountability and knowledge workers: A potential unifying theme for managerial and auditing research', Advances in Management Accounting, 2, 47-61; Gavin J.N. \& Geoffrey auditing research', Advances in Management Accounting, 2, 47-61; Gavin J.N. \& Geoffrey G.C., 2004, 'Corporate Governance, Break through Board Performance', Journal of Public 'Basic individual values, work values, and the meaning of work', Applied Psychology: An International Review 48(1), 49-71.

FIGURE 1: Conceptual framework showing the relationship between corporate governance and financial performance of non-governmental organisations in War Child Uganda.

viewpoint of accounting information control when subordinates find themselves operating outside a structured and measured framework (Birnberg, Turopolec \& Young 1983). The six dimensions of disclosure-related behaviour identified and operationalised are smoothing, biasing, focusing, gaming, filtering and illegal acts. Financial performance vested in liquidity, reporting, budgeting and accountability was measured using the already established instruments developed by Wang, Tsui and Xind (2003).

\section{Literature review on corporate governance and financial performance}

This section provides a discussion of the theoretical and empirical literature related to this study.

Jensen and Meckling's 1976 article on theory of the firm, entitled 'Management behavior, agency, cost and ownership structure', helped establish the agency theory as the dominant theoretical framework of corporate governance (Daily, Dalton \& Cannella 2003; Lan \& Heracleous 2010). Berle and Means (1993) discuss the issues regarding separation between ownership and control in large organisations, and the theory of the firm became widely accepted when Jensen and Meckling (1983) formulated the agency problem in governance of organisations.

This study is guided by the agency theory, which is defined as the relationship between the board of directors of NGOs or agency and the agents who are managers. It explains that 
the board of directors usually delegate authority to agents. However, the organisation's objectives may not be obtained because the agents/managers with whom the board of directors have been entrusted usually act opportunistically to obtain their own interests, thus creating conflict. To address the agency problems, the board of directors should ensure efficient monitoring of activities. If monitoring is not done, the organisation incurs hefty costs in the process of ensuring that the managers' activities are aligned to the organisation's work plans, goals and objectives. This theory was relevant in the study because it explains the relationship between directors and managers in NGOs.

\section{Corporate governance and financial performance}

Corporate governance is broadly defined as the system by which a company's processes are directed and controlled in the pursuit of creating and maximising shareholder value (Institute of Directors, Southern Africa 1994). Parker (2007) states that a paradigm of the separation of shareholder ownership and management's control shows that agency problems occur when the principles (stakeholders) lack the necessary power or information to monitor and control the agents (managers). This implies that the corporate governance mechanisms employed could affect the financial performance by increasing the manager's sensitivity towards the stake holder's preferences.

A more recent definition of corporate governance is provided by Khan (2019) as a description of processes, customs, policies, laws and institutions which direct institutions, organisations and corporations in the way they act, administer and control their operations. Corporate governance aims at achieving the goals, mission and vision of organisations.

Youssef (2007) also states that corporate governance is the process carried out by the board of directors, and its related committees, on behalf of and for the benefit of the company's shareholders and other stakeholders to provide direction, authority and oversights to management. This means how to make the balance between the board members and their benefits and the benefits of the shareholders and the other stakeholders. Currently, financial sectors have seen the importance of having good corporate governance practices (Kolk \& Pinkse 2009). According to Claessens and Fan (2003), poorly governed firms are expected to be less profitable.

Leaders in many countries all over the world have increased concerns over corporate governance because of the increase in the reported cases of fraud, inside trading and agency conflicts amongst corporations (Enobakhare 2010). This is also supported by Ahmad (2009) who argued that a sound banking system requires appropriate infrastructure to support an efficient conduct of banking business, such as operating environment, governance and regulatory framework at domestic and international levels. This is done with the aim of avoiding and reducing bank crises.

\section{Accountability}

According to Boice (2004), accountability refers to financial responsibility or operational transparency that requires demonstrating how donations in the organisation are used and how effectively the organisation achieves its goals. Tilt (2007) argues that the most important issue when considering accountability of NGOs is the means by which they will be required to provide an account. Marshall (2002) also adds that the most obvious way to ensure that NGOs are transparent is a full disclosure of their activities, which will enhance public trust.

Most empirical works (Ho 2005) carried out have revealed positive findings, while some, like Brown and Caylor (2004), have concluded that although there is a link between audit quality, governance and financial performance, the significance of the relationship lies between audit quality and dividend yield and not with operating performance. Matama (2006) in the study of corporate governance and financial performance on selected commercial banks accepted the hypothesis that there is a positive relationship between corporate governance and financial performance.

\section{Transparency}

Kaufmann and Kraay (2002) define transparency as the increased flow of timely and reliable economic, social and political information, which is accessible to all relevant stakeholders. Similarly, but focusing specifically on economic transparency, considers the timely availability of economic data as the basis of their transparency index.

Patel, Basic and Bwakira (2002) found that firms with higher transparency and disclosure are valued higher than comparable firms with lower transparency and disclosure, consistent with the notion that the market places a premium on companies with lower asymmetric information problems. Sadka and Korajczyk (2005) provide both empirical and theoretical evidence that the public sharing of financial and market transparency has enhanced factor productivity and economic growth.

Gelos and Wei (2002) observed that in countries that ensure transparency, fund managers are willing to wait for further confirmation before engaging in a costly reallocation of assets, whereas lack of transparency seems to make investors somewhat suspicious of economic news.

Fundamentally, corporate disclosure and transparency are vital for a strong corporate governance framework. Transparency, which is a desirable characteristic of financial reporting, can be defined as 'the extent to which financial reports reveal an entity's underlying economy in a way that is readily understandable by those using the financial reports' (Barth \& Schipper 2008). The need for accurate, reliable, timely and accessible financial and non-financial business information is imperative in order to maintain corporate accountability. 


\section{Competency}

Munene, Bbosa and Eboyu (2006) define competency as the relationship between an employee and his or her environment, whereby when an individual manoeuvres the environment in which he is, and becomes successful, he or she is considered competent. A number of aspects explain competence, which include personal skills, knowledge of a subject matter, emotions, traits, self-merging and social roles (Boyatzis 2000). Competences can also be operant competences such as having specific skills, knowledge, attitudes and behaviours necessary to fulfil a given task (Munene, Mulira \& Kasekende 2008).

Brophy and Kelly (2002) say that a competence is a word that can be used to describe a feature of a personal ability to perform one's job effectively. Thompson and Strickland (2004) also consider building core competence capabilities as a key component of building a capable organisation. It will enable the execution of a good strategy and maintain a competence or capability portfolio.

Festo and Nkote (2013) carried out a study on board governance and firm performance of selected state-owned corporations and listed organisations on the Uganda Securities Exchange and found a positive direct and indirect link between board governance and firm performance through board effectiveness. In addition, Chiang (2005) conducted an empirical study on the relationship between governance characteristics and operating performance in Taiwan's high-tech industry and found that variables such as board size, board ownership, institution ownership, information transparency and board and management structure affect performance.

\section{Conduct}

The code of conduct should set out ethical and behavioural expectations for both directors and employees. It is critical that both the board and the senior management team demonstrate absolute commitment to that code through both their words and actions as they show competence in executing their duties (Australia 2003).

Klapper, Laeven and Love (2006), Iyang (2009), Sasuni (2003) and Soludo (2004) suggested that most corporate governance codes are instituted by self-regulating professional bodies with the consent of the relevant government regulating agencies. However, the responsibility for adopting and implementing the code lies on a corporation board of directors. The corporate governance codes are best enforced by professional bodies in collaboration with government institutions and vice versa (Wilson 2006). Furthermore, Reed (2002) observed that corporate governance mechanisms are the process and system by which a country's laws and corporate governance codes are enforced. The mechanisms incorporate the means for monitoring compliance by corporation. However, as suggested by Wilson (2006), Dabor and Adyemi (2009) and Ahmed (2007), the effectiveness of a country's corporate mechanism depends largely on the country's regulatory framework and public governance systems.

It is believed that higher levels of managerial compensation usually encourage directors to perform their role more effectively because higher performance is expected from them. Conyon and Schwalbac (2000) have argued the existence of such a relationship, while others have failed to find an empirical support for such a relationship. For instance, Duffhues and Kabir (2008) argued that this predominant insight of a link between the two variables is not necessarily valid because they did not report any significant relationship between executive pay and corporate performance.

\section{Reporting}

According to Choudhury and Ahmed (2002), poor quality of financial reports greatly diminishes the quality of NGOs. Quality information is one that is readable, reliable, comparable, consistent, complete, timely, decision-useful, accessible and cost-effective. The integrity of the non-profit sector is served best if NGOs are accountable.

In order to make the information provided in financial statements useful to users, the reporting entities ought to provide quality information (Choudhury \& Ahmed 2002). Choudhury defines quality information as one that is readable, reliable, consistent, accurate, complete, timely, accessible and cost-effective. The conceptual framework of accounting also identifies relevancy, reliability, understandability and comparability as the principal qualitative characteristics of appropriate accounting standards. This normally results in financial statements that convey what is generally understood as a true and fair information.

\section{Budget performance}

Performance budgeting is an integrated annual performance plan and annual budgeting that shows the relationship between programme funding levels and expected results. It indicates that a goal or a set of goals should be achieved within a specified level of spending. Performance budgeting identifies the relationships between money and results, as well as explaining how those relationships are created. Ndiwalana (2009) argued that the act of participating in budget processes serves as a function whose duty is to induce employees to accept and commit to their budgeting goals. Ndiwalana further argued that when employees participate in budgeting, it will result in reduced costs, improved motivation and job commitment and therefore an enhanced performance.

Eyong (2001) states that there is a strong relationship between organisations being perceived as honest, ethical in their ability to use funds and having high levels of public confidence in the organisations' governance structures. This usually results in increased funding for the organisation. Keating and Frumkin (2003) argue that the economic success 
of communities in which the not-for-profit organisations operate, depends not only on the quality of its socio-economic activities, but also on improving its internal accounting and external financial reporting systems. Hughes (2003) agrees with this argument by stating that it is governance, through organisational capacity, not accountability that challenges not-for-profit organisations most.

\section{Liquidity}

Liquidity refers to the ability of a firm to meet its financial obligations in a timely manner. In essence, the assets owned by a company are liquid if they can quickly and cheaply be converted to cash (Brealey et al. 2000). The critical performance issue relative to liquidity is whether the organisation has or is developing enough readily accessible capital to continue to operate. Accordingly, liquidity measures represent one aspect of a dimension of overall organisational performance, but are not sufficient measures by themselves to represent the entire construct.

Corporate governance has been identified as having a significant impact on the performance of firms (Coleman \& Osei 2007; Dittmar \& Mahrt-Smith 2007). However, according to Hermalin and Weisbach (2010), there does not seem to be consistent evidence to support the fact that board size or composition affects performance. According to Kairu (2011), an appraisal of the performance of the cooperative movement by the parliamentary committee on finance revealed that local NGOs are faced with numerous operational hurdles, some of which include poor governance and regulatory issues emerging as key challenges. Wright and Staw (1999) observed that most stakeholders, including government officials, were wary about their future local NGOs because of their poor performance and inherent governance problems. Wright however noted that good governance had enabled Uganda to witness some levels of acceptable progress in terms of how local NGOs' matters are managed.

A firm's recommitment to the timely disclosure of high-quality financial accounting information reduces investors' risk of loss from trading with more informed investors, thereby attracting more funds into the capital markets, lowering investors' liquidity risk (Botosan 2005; Brennan \& Tamarowski 2000; Leuz \& Verrecchia 2000).

Leuz and Verrecchia (2000) studied corporate governance based on a stakeholder-agency paradigm in which the managers can be seen as the agents of various stakeholders and found that the corporate governance mechanisms employed affected the company's environmental financial performance by increasing the managers' sensitivity towards the stakeholders' environmental preferences. More specifically, the empirical evidence showed that companies that had a greater exposure to the market for corporate control also had a lower representation of pro-stakeholder directors on their boards, and a superior level of financial performance. Hermalin and Weisbach (2010) argued that larger boards can be less effective than smaller boards. They further stated that too many members on a board may create agency problem, and some members may be considered free riders without corresponding impact to relevant decisionmaking. More recent empirical studies have supported this finding, where Jensen (2003) noted that large board sizes can be disadvantageous and expensive for firms.

Chen and Silverthorne (2008) in his study of 923 large firms from 1998 to 2004 concluded that the multiple directorship has implications for both the costs and benefits to the firm. He found that firms with high growth opportunities and low agency conflict have less problems, which can be an advantage in terms of seeking advice for improvement of the firm. Kajola (2008) examined the relationship between four corporate governance mechanisms (board size, board composition, chief executive status and audit committee) and return on equity (ROE) and profit margin (PM), considering a sample of 20 Nigerian listed firms between 2000 and 2006. The International Journal of Economics, Commerce and Management, United Kingdom, Licensed under Creative Common Page 397, used the panel methodology as a method of estimation of states. It was found that there is a positive significant relationship between ROE and board size, as well as the chief executive status.

\section{Critics of past studies and research gaps}

Hermalin and Weisbach (2010) studied corporate governance of companies listed on the stock exchange but ignored NGOs. They mainly focused on board size as a measure of corporate governance. Corporate governance is a wider concept that should be measured by many other variables, such as board diversity, independency and accountability. This study measures financial performance in terms of non-profitability ratios, such as budget burnout rates on programme expenses, fund raising ratio and working capital ratio. This is divergent from previous studies that measured financial performance of organisations using profitability ratio analysis such as returns on investment and return on capital employed.

\section{Methodology of the study}

This study adopted cross-sectional and descriptive research designs using quantitative and qualitative approaches. The study focused on a target population of 110 employees: 45 from WCH, 40 from WCUK and 25 from WCC as per information from the human resources personnel in 2012 (HRM War Child). The study targeted top- and middle-level management members because they are the custodians of internal control. Accordingly, all departmental heads were targeted as respondents; however, greater emphasis was laid on capturing members in finance and finance-related offices.

Purposive sampling was used to identify members of the senior management team, whereas stratified random sampling was used to identify the group of respondents from 
their respective departments. Simple random sampling was used to select the target staff from each of the War Child institutions in Uganda.

The Krejcie and Morgan table was used to determine the sample size of randomly chosen individuals from a given finite population of $N$ cases where the sample proportion $P$ was within \# 0.05 of the population $P$ with a $95 \%$ level of confidence (Krejcie \& Morgan 1970). This table indicated that if the population size is 110 , a statistically representative sample size would be 86 respondents. This sampling strategy was used because of the basic law of probability and it assures the researcher of an utmost representation of the total population within an accepted margin of error as shown below:

- $s=\mathrm{X}^{2} \mathrm{NP}(1-P) \div \mathrm{d}^{2}(N-1)+\mathrm{X}^{2} \mathrm{P}(1-P)$

- $s=$ required sample size

- $X^{2}=$ the table value of chi-square for 1 degree of freedom at the desired confidence level(3.841)

- $N=$ the population size.

- $P=$ the population proportion (assumed to be 0.50 as this would provide the maximum sample size)

- $d=$ the degree of accuracy expressed as a proportion (0.05).

To collect qualitative data, key informant interviews (KII) were administered to the top management and heads of departments dealing with financial performance issues. Key informant interviews were used because of their ability to explore in-depth and elaborate information from 'knowledgeable' people on a particular subject. White (2000) suggests that using KII is a cheap data collection option to consider.

For quantitative data collection, a questionnaire was administered to collect facts and document evidence. The questionnaire method was used because it eliminates the elements of shyness amongst respondents. The respondents were given enough time to avail accurate answers and opinions. The questionnaire technique included only closedended questions for the purpose of having all the questions answered.

Corporate governance was measured using a 5-point interval Likert scale, ranging from 1 'strongly disagree' to 5 'strongly agree', developed by Gavin and Geoffrey (2004).

Financial performance was also measured using a 5-point interval Likert scale, ranging from 1 'strongly disagree' to 5 'strongly agree', developed by Wang et al. (2003).

The Cronbach's alpha coefficient and the Content Validity Index were used to assess the reliability and validity of the research instrument, respectively. The values for these coefficients are as shown Table 1.

\section{Ethical consideration}

Consent from all the respondents who took part in the study was obtained and confidentiality was maintained in conducting this research.
TABLE 1: Reliability and validity of the research instrument.

\begin{tabular}{lccc}
\hline Variable & Anchor & $\begin{array}{c}\text { Cronbach's alpha } \\
\text { coefficient }\end{array}$ & $\begin{array}{c}\text { Content Validity } \\
\text { index }\end{array}$ \\
\hline Corporate governance & 23 & 0.766 & 0.800 \\
Financial system & 18 & 0.781 & 0.701 \\
Financial performance & 23 & 0.792 & 0.692 \\
\hline
\end{tabular}

Note: Data from Table 1 show that the Cronbach's alpha coefficient and the Content Validity index were above 0.700 , indicating that the research questionnaire instrument was both valid and reliable.

\section{Key findings of the study}

The results below indicate the findings that were generated after the data were gathered, cleaned, entered and analysed. They were generated using the background characteristics and inferential statistics. Amongst the statistics used were the cross tabulations and correlations.

\section{Awareness levels of staff of War Child about the existence of financial systems that lead to financial performance in War Child in Uganda}

The management of War Child in Uganda highly recognises financial systems; it encourages activities such as planning, research stocks commodities, bonds and other financial instruments to make recommendations and prepare reports. The three network organisations are aware of the financial systems in the organisation and the disclosure failure implication on both financial and non-financial information (social, governance, environment, economy, health of the community and human rights) in terms of discrimination, sexual harassment, health and safety, access to information, torture, freedom of expression, privacy, poverty, food and water, education, housing and so on.

\section{War Child Holland}

This organisation ensures that there is accurate, complete and timely bookkeeping, processing cash and bank transactions, keeping overview of advances and ensuring timely clearance and payment of overviews. An example is rental contracts and insurance communications, as well as ensuring timely follow-up, scanning and filling finance documentation; all the above process is done in line with the financial procurement policies of $\mathrm{WCH}$.

\section{War Child UK}

It ensures preparation of quality and timely financial reports, support in development and implementation of finance policies and procedures. It also ensures that financial standard calls are maintained.

\section{War Child Canada}

It ensures maintenance of internal expenditure, preparation of all types of payment vouchers, cash flow planning and preparation of accurate and high-quality monthly financial reports. It also ensures that the reports are submitted to the donors in a timely manner. 


\section{The relationship between corporate governance and financial performance of War Child in Uganda}

Table 2 shows the relationships between the study variables that were generated using the Pearson (r) correlation coefficient. The Pearson $(r)$ correlation coefficient varies between -1.00 and 1.00 .

The results in Table 2 show that there is a moderate positive relationship between corporate governance and financial performance of War Child in Uganda $\left(r=0.491^{* *}, p<0.01\right)$ and this relationship is statistically significant. The double asterisks mean the relationship tested is a two-tailed investigation (can be either positive or negative relationship amongst the two studied variables). These results show that if War Child organisations go through oversight and embrace corporate governance of accountability, transparency, competency, role clarity and conduct in their institutional maker-up, they are most likely to improve on their financial performance. This will be evident in terms of improved financial accountability, reporting, budget performance and liquidity.

\section{The factor structure of corporate governance and financial performance of War Child in Uganda}

Factor analysis was used to explore the nature of the variables used in this particular study.

\section{Corporate governance}

Table 3 shows the factor structure of the corporate governance.

The corporate governance variable was noted to be mainly composed of accountability, transparency, competency, role clarity and conduct attributes. These five attributes explain the cumulative variance of $71.171 \%$ of the main variable of which transparency was observed as having a percentage score of $30.746 \%$ variance of the main variable; accountability presented with $12.327 \%$, then competency with $11.294 \%$, role clarity $8.111 \%$ and conduct $9.232 \%$.

\section{Financial performance}

Table 4 shows the factor structure of the financial performance.

The results in Table 4 show that the financial performance variable is mainly composed of financial accountability, reporting, budget performance and liquidity attributes, and these four explain the accumulative variance of $62.478 \%$ of the main variable. This provides the budget performance with the corresponding percentage score of $30.846 \%$ of the main variable. The other three attributes are financial accountability, reporting and liquidity of the financial performance specifically account for $11.294 \%, 12.327 \%$ and $8.111 \%$ variances, respectively.

\section{Discussion of key findings}

The discussion was done by exploring the research findings relative to what other researchers in the fields that pertain to the variables have confirmed. Discussion of the study was guided by the study objectives.

TABLE 2: Relationship between corporate governance and financial performance.

\begin{tabular}{lcc}
\hline Variable & Corporate governance & Financial performance \\
\hline Corporate governance & 1.000 & $0.491 \dagger$ \\
Financial performance & $0.491 \dagger$ & 1.000 \\
\hline
\end{tabular}

$\dagger$, Correlation is significant at the 0.01 level (two-tailed).

TABLE 3: Corporate governance factor analysis results.

\begin{tabular}{|c|c|c|c|c|c|}
\hline Factor analysis results: Employee resilience & Accountability & Transparency & Competency & Role clarity & Conduct \\
\hline Good corporate governance is important & 0.686 & - & - & - & - \\
\hline Manager who has not been contributing to help employees & 0.560 & - & - & - & - \\
\hline Management members bind themselves to uphold employee values & 0.800 & - & - & - & - \\
\hline Proposals from employees are analysed and considered & - & 0.506 & - & - & - \\
\hline Management team receives accurate minutes & - & 0.501 & - & - & - \\
\hline All managers are fully informed of relevant matters & - & 0.668 & - & - & - \\
\hline Management meetings are conducted in a manner that is professional & - & 0.536 & - & - & - \\
\hline There is information on management information requirements & - & 0.764 & - & - & - \\
\hline There is ethical or professional conduct at work & - & 0.698 & - & - & - \\
\hline Management meetings are facilitated & - & 0.809 & - & - & - \\
\hline The selection process considers any insufficiencies & - & 0.798 & - & - & - \\
\hline The management ensures that its member are catered for & - & - & 0.637 & - & - \\
\hline Management has the ability to fulfil its duties & - & - & 0.570 & - & - \\
\hline Management identifies and uses the specific talents & - & - & 0.587 & - & - \\
\hline All management members are permitted to contribute to decision-making & - & - & - & 0.536 & - \\
\hline Task delegation to management is represented & - & - & - & 0.571 & - \\
\hline Management sets measurable objectives that permit staff to adhere to & - & - & - & 0.667 & - \\
\hline Every management member receives copies of all documents & - & - & - & - & 0.677 \\
\hline New management members are introduced to staff & - & - & - & - & 0.587 \\
\hline Management develops a regular policy for managing work & - & - & - & - & 0.611 \\
\hline Eigen-value & 4.612 & 1.849 & 1.694 & 1.217 & 2.113 \\
\hline Variance $\%$ & 12.327 & 30.746 & 11.294 & 8.111 & 9.232 \\
\hline Cumulative \% & 12.327 & 43.073 & 54.367 & 62.478 & 71.171 \\
\hline
\end{tabular}


TABLE 4: Financial performance factor analysis results.

\begin{tabular}{|c|c|c|c|c|}
\hline Factor analysis results: Financial performance & Financial accountability & Reporting & Budget performance & Liquidity \\
\hline Every financial transaction at this organisation has to be followed up & 0.686 & - & - & - \\
\hline Internal audit independently verifies and validates the financial performance & 0.560 & - & - & - \\
\hline Our organisation demonstrates legality, probity, accuracy & 0.800 & - & - & - \\
\hline Accounts activities are monitored and supervised & 0.667 & - & - & - \\
\hline Tenders are awarded in line with established regulations & 0.564 & - & - & - \\
\hline Funding arrangements for any activity at this organisation are ensured & 0.611 & - & - & - \\
\hline Accountability format in this organisation is done as per guidelines & 0.701 & - & - & - \\
\hline When advances are given, accountabilities are very slow & 0.567 & - & - & - \\
\hline Financial reports are timely produced & - & 0.506 & - & - \\
\hline Financial reporting in this organisation complies with rules and regulations & - & 0.679 & - & - \\
\hline All stakeholders are always satisfied with the organisation & - & - & 0.637 & - \\
\hline Management periodically produces cash flows & - & - & 0.501 & - \\
\hline Financial statements on their own are entirely well made & - & - & 0.801 & - \\
\hline The value for money audits is regularly carried out in the organisation & - & - & 0.798 & - \\
\hline In this organisation accountability is always done & - & - & 0.598 & - \\
\hline Funds are spent as planned & - & - & 0.810 & - \\
\hline Management has the tendency to spend funds on items not planned for & - & - & 0.710 & - \\
\hline Management has the tendency to spend funds on items planned for & - & - & 0.592 & - \\
\hline Management monitors performance against objectives & - & - & 0.623 & - \\
\hline Management periodically produces balance sheets & - & - & - & 0.536 \\
\hline Division of funds occurs when in the organisation & - & - & - & 0.571 \\
\hline Eigen-value & 4.612 & 1.849 & 1.694 & 1.217 \\
\hline Variance \% & 11.294 & 12.327 & 30.846 & 8.111 \\
\hline Cumulative \% & 11.294 & 23.621 & 54.367 & 62.478 \\
\hline
\end{tabular}

\section{Awareness levels of staff of War Child about the existence of financial systems that lead to financial performance in War Child in Uganda}

The results showed that the management of War Child in Uganda highly recognises financial systems; they engage in activities such as accounting measures, revenue and expense schedules, wages and balance sheet verifications, cash instruments (e.g. loans, deposits and securities), planning, preparing reports and costs. The three organisations are aware of the financial systems in the organisation, although they fall short of the non-financial reporting. However, if the staff of these organisations put more effort in ensuring that the knowledge they have about financial systems is followed as per stipulated guidelines, then they would be in a position to attain higher levels of financial performance in War Child.

\section{The relationship between corporate governance and financial performance of War Child in Uganda}

The results showed a moderate positive relationship between corporate governance and financial performance of War Child in Uganda $\left(r=0.491^{* *}, p<.01\right)$, and this relationship is statistically significant. The double asterisks mean the relationship tested is a two-tailed investigation (can be either positive or negative relationship amongst the two studied variables). These results show that if War Child organisations go through their oversight and embrace corporate governance of accountability, transparency, competency, role clarity and conduct in their institutional maker-up, they are most likely to improve on their financial performance, and this will be evident in terms of improved financial accountability, reporting, budget performance and liquidity.

\section{The factor structure of the corporate governance and financial performance of War Child in Uganda}

The results of the factor analysis indicated that the financial performance of War Child in Uganda is dominantly composed of budget performance with a variance of $30.846 \%$, which comprised a greater share of the variable, and corporate governance was dominated by transparency with a variance of $30.746 \%$.

For each of the variables indicated in the factor analysis, the most important attributes are the ones with the greatest variance percentage and these attributes should be considered first in case the variables are to be taken advantage of and improved upon by War Child. This can be done with the aim of improving their financial performance. After the most dominant attributes are dealt with, War Child should work on the second most important attributes in the order they are indicated - beginning with the one that explains the greatest percentage of the variable to the one that explains the least. If this is done, it will help ensure that there is a positive relationship between the variables.

From an overview of the NGO accountability literature over the last 10 years, there are two kinds of accountability for NGOs that are outlined: 'performance' accountability and 'voice' accountability (Slim 2002). The task of providing statements of income and expenditure, description of programmes, targets and achievements is less subjective than providing an account of goals and missions. According to the 2001 Institute of Corporate Governance of Uganda, corporate governance should put in place a framework 
to ensure timely and accurate disclosure of all materials permitted to be shared in regards to the corporation. This includes the financial situation, performance, ownership and the governance of the company. Fundamentally, corporate disclosure and transparency are vital for a strong corporate governance framework (Schipper 2008). Likewise, some other researchers like Caylor (2004) reported a positive relationship between the quality of corporate governance and their measures of profitability.

\section{Recommendations}

The following are the recommendations that should be implemented so as to ensure improved financial performance of War Child in Uganda.

\section{Awareness levels of staff of War Child about the existence of financial systems that lead to financial performance in War Child in Uganda}

The institutions of War Child in Uganda need to emphasise aspects such as an increase in supervision of the staff members at work to ensure that they are more productive according to the organisation's mission and vision.

There is a need to ensure that the staff members are carrying out duties as assigned in order to avoid cases of dealing with the consequences of laziness or neglect of duty.

There should also be efforts to motivate the staff members to pursue work-related tasks. This will allow War Child in Uganda to meet its goals in terms of the application of financial systems. This will lead to an increase in financial performance.

Training and building the capacity of the staff can also be put into consideration. Building capacity of staff based on their need will give them avenues for development in terms of financial systems which can contribute to better financial performance in line with new developments.

\section{The relationship between corporate governance and financial performance of War Child in Uganda}

Despite NGOs', such as War Child, importance in and contribution to the country, there is a need for these institutions to watch and manage challenges they face related to regulating agencies, laws and policies governing their operations.

There is a need for War Child to embrace and incorporate continued corporate governance as this shields firms from vulnerability to future financial distress, attracting investment and raising funds, goodwill and confidence.

There is a need for War Child to monitor its corporate governance systems as recent corporate scandal debates have been caused by corporate governance failures.
War Child at all times needs to be accountable, both performance- and voice-wise for their activities, to the public and donors.

War Child should put in place a framework that is transparent and confidential to balance and ensure timely and accurate disclosure of all material matters regarding the institution.

Transparency and disclosure by War Child should be emphasised as it leads to a firm being highly valued but with a strong corporate governance framework.

War Child in Uganda needs to comply with voluntary codes of good governance conduct, set out ethical and behavioural expectations for both employees and clients and enforce them through professional bodies and in collaboration with government institutions.

There is a need for both 'upward' and 'external' accountability to donors and the development of 'downward' and 'internal' mechanisms as key elements in financial resource mobilisation.

\section{Areas of further research}

A number of key issues were identified during the course of the study. Future researchers should therefore investigate the following study themes:

- appropriateness of supervision policies in NGOs in handing financial performances

- comprehensive study in connection with the construction and design of an effective early warning system to prevent and detect fraud and embezzlement.

\section{Conclusion}

In light of the above-stated findings and the discussion of the results, the following conclusions were drawn so as to logically guide the beneficiaries of the study.

There was concrete evidence that the staff of War Child in Uganda are completely aware of the financial systems, although they fall short in non-financial reporting. The study findings indicate that all the bodies under War Child in Uganda should allocate responsibilities to particular staff members to ensure that they operate and follow these financial systems, which in turn will help obtain high levels of financial performance. However, if the staff of these organisations put more effort in ensuring that the knowledge they have about financial systems is followed as per the guidelines, then they would be in a position to attain higher levels of financial performance in War Child. There was a moderate positive relationship between corporate governance and financial performance of War Child in Uganda $\left(r=0.491^{* *}, p<.01\right)$ and this relationship is statistically significant.

For instance, when War Child embraces good corporate governance through accountability, transparency, competency, role clarity and conduct in their institutional maker-up and practice, it is most likely to improve on its financial performance 
and this will be evident in terms of improved financial accountability, reporting, budget performance and liquidity. Factor analysis results indicated that financial performance of War Child in Uganda is dominantly composed of budget performance attribute, with a variance of $30.846 \%$, and this comprised a greater share of the variable; corporate governance was dominated by transparency attribute, with a variance of $30.746 \%$. These are the main attributes that should be considered first in case the variables are to be taken advantage of and used to improve on War Child's financial performance.

\section{Acknowledgements}

The authors would like to thank Nyamburu Dorothy who helped with the primary data collection as a research assistant.

\section{Competing interests}

The authors declare that they have no financial or personal relationships which may have inappropriately influenced them in writing this article.

\section{Author's contributions}

M.K. collected the primary data and ensured the analysis of both qualitative and quantitative data. She also drafted the article. T.S. helped with secondary data collection, quantitative data analysis and editing of the article.

\section{References}

Ahmed, M., 2007, Corporate governance: A new fad or an important development prerequisite? Paper presented at the British council's management Express forum Calabar, Nigeria.

Ahmad, A., 2009, Identity theft: A study on fraud prevention initiatives at local Islamic Bank, Master dissertation, Faculty of Accountancy, Universiti Teknologi Mara, Shah Alam

Alexander, D. \& Britton, A., 1993, Financial reporting, 3rd edn., Chapman \& Hall, London.

Alo, O., 2003, Issues in corporate governance, Financial Institution Training Center Lagos.

American Institute of Certified Public Accountants (AICPA), 2010, 'The importance of internal controls in financial reporting and safeguarding of assets', Nigerian Economic Society Journal, viewed 09 April 2019, from https://books.google.co.ug/ books?id=C4IhDAAAQBAJ\&pg=PA251\&lpg=PA251\&dq =.+Alo, +O., $+(2003)+$, corpo rate+governance\&source=bl\&ots=2B9GGCRmDv\&sig=ACfU3U14siz336tQBvkLLtc HAkbcjd91HQ\&hl=en\&sa=X\&ved=2ahUKEwijp_nM_vngAhWiRBUIHQITDs4Q6AE wAXoECAgQAQ\#v=onepage \&q =. $\% 20 \mathrm{Al} \% \% 2 \mathrm{C} \% 200 . \% 2 \mathrm{C} \% 20(2003 \% 2 \mathrm{C}) \% 20$ corporate $\% 20$ governance $\& \mathrm{f}=$ false

Armstrong, C. \& Larcker, D., 2009, 'Discussion of "the impact of the options backdating scandal on shareholders" and "taxes and the backdating of stock option exercise dates"', Journal of Accounting and Economics 47, 50-58. https://doi.org/10.1016/j. jacceco.2008.11.005

Association of Certified Chartered Accountants (ACCA), 2004, Preparing financial statements, Foulks Lynch, London.

Atwater, L., Waldman, D., Ostroff, C., Robie, C. \& Johnson, K.M., 2005, 'Self-othe agreement: Comparing its relationship with performance in the US and Europe', International Journal of Selection and Assessment 13(1), 25-39. https://doi. org/10.1111/j.0965-075X.2005.00297.x

Bagley, C.E., 2002, Managers and the legal environment: Strategies for the 21st century, Thomson Learning, Cincinnati, $\mathrm{OH}$.

Baker, T., Collins, D. \& Reitenga, A., 2003, 'Stock option compensation and earnings management incentives', Journal of Accounting, Auditing, and Finance 18(4), 557-582. https://doi.org/10.1177/0148558X0301800408

Barth, M.E. \& Schipper, K., 2008, 'Financial reporting transparency', Journal of Accounting, Auditing \& Finance 23(2), 173-190. https://doi.org/10.1177/01485 $58 \times 0802300203$

Bauer, R., Gunster, N. \& Otten, R. 2004, 'Empirical evidence on corporate governance in Europe: The effect on stock returns, firm value and performance', Journal of Asset Management 5(2), 91-104. https://doi. org/10.1057/palgrave.jam.2240131
Beiner, S., Drobetz, W., Schmidt, M. \& Zimmerman, H., 2004, An integrated framework of corporate governance and firm valuation - evidence from Switzerland, ECGI Working Paper in Finance No. 34/2004. University of Basel, viewed 09 April 2019 from https://www.researchgate.net/publication/228945458_An Integrated, from https://www.researchgate.net/publication/228945458_An_Integrated_Framework_ Switzerland.

Bergstresser, D. \& Philippon, T., 2006, 'CEO incentives and earnings management', Journal of Financial Economics 80(3), 511-530. https://doi.org/10.1016/j.jfineco. 2004.10.011

Berle, A.A. \& Means, G.C., 1933, The modern corporation and private property, Macmillan, New York. ISBN 978-0-88738-887-3.

Birnberg, J.G., Turopolec, L. \& Young, S.M., 1983, 'The organizational context of accounting', Accounting Organization and Society 8(2/3), 111-129. https://doi. org/10.1016/0361-3682(83)90018-1

Birnberg, J.G. \& Heiman-HoVman, V., 1993, 'Accountability and knowledge workers: A potential unifying theme for managerial and auditing research', Advances in Management Accounting 2, 47-61.

Black, B., 2001, 'The corporate governance behavior and market value of Russian firms', Emerging Markets Review 2(2), 89-108. https://doi.org/10.1016/S15660141(01)00012-7

Boice, J., 2004, The accountability, viewed 21 July 2004, from www.afpet.org/ contntdocuments/marap04cover.pdf.

Botosan, C., 2005, 'Evidence that greater disclosure lowers the cost of equity capital', Journal of Applied Corporate Finance 12(4), 2-127, viewed 09 April 2019, from https://onlinelibrary.wiley.com/doi/abs/10.1111/j.1745-6622.2000.tb00019.x

Boyatzis, R., 2000, 'Clustering competence in emotional intelligence: Insights from the emotional competence inventory (ECI)', in Handbook of emotional intelligence, Department of Organizational behaviour, Case Western Reserve University, Cleveland, viewed 09 April 2019, from https://weatherhead.case.edu/ departments/organizational-behavior/workingPapers/WP\%2099-6.pdf

Brealey, R., Myers, S., Partington, G. \& Robinson, D., 2000, Principles of corporate finance, 1st Australian edn., McGraw-Hill, Sydney.

Brennan, M. \& Tamarowski, C., 2000, 'Investor relations and stock prices', Journal of Applied Corporate Finance 12(4), 26-37.Brett, J.M. \& Stroh, L.K., 2003, 'Working 61 plus hours a week: Why do managers do it?', Journal of Applied Psychology 88, 67-78. https://doi.org/10.1037/0021-9010.88.1.67

Brief, A., 1998, Attitudes in and around organizations, Sage, Thousand Oaks, CA.

Brody, A., 2001, Accountability and public trust. In the State of America's nonprofit sector, Fordham Law Review.

Brophy, M. \& Kelly, T., 2002, 'Competencies: A new sector', Journal of European Industrial Training 26, 165-176. https://doi.org/10.1108/03090590210422049

Brown, S. \& Caylor, D., 2004, 'Corporate governance and firm performance', European Financial Management 2(10), 151-170.

Buchko, A.A., 2007, 'The effect of leadership on values-based management', Leadership \& Organization Development Journal 28(1), 36-50. https://doi org/10.1108/01437730710718236

Cavill, S. \& Sohail, M., 2007a, Accountability arrangements to combat corruption, Department for International Development or WEDC, Loughborough University, ISBN: 978184380112 2, viewed 09 April 2019, from http://www.lboro.ac.uk/ wedc/publications/.

Cavill, S. \& Sohail, M., 2007b, 'Increasing strategic accountability: A framework for international NGOs', Development in Practice 17(2), 231-248. https://doi.org/ 10.1080/09614520701196004

Chen, J.-C. \& Silverthorne, C., 2008, 'The impact of locus of control on job stress, job performance and job satisfaction in Taiwan', Leadership \& Organization Development Journa/29(7),572-582. https://doi.org/10.1108/01437730810906326

Cherrington, D.J., 1980, The work ethic: Working values and values that work, Amazon, New York.

Chiang, H.-T., 2005, 'An empirical study of corporate governance and corporate performance', The Journal of Law and Economics 31(1), 122-140.

Choudhury, E. \& Ahmed, S., 2002, 'The shifting meaning of governance: Public accountability of third sector organization in an emergent global regime" International Journal of Public Administration 25(4), 561-588. https://doi.org/ 10.1081/PAD-120013256

Claessens, S. \& Fan, J., 2003, Corporate Governance in Asia: A survey: Internationa review of finance, Wiley Online Library. https://doi.org/10.1111/1468-2443.00034

Coleman, A.K. \& Osei, K.A., 2007, 'Outreach and profitability of microfinance institutions: The role of governance', Journal of Economic Studies 35(3), 236-248. https://doi.org/10.1108/01443580810887797

Collins, D.J. \& Collins, R.H., 1978, A guide to church accounts, Bocardo \& Church Army Press Ltd., Oxford.

Conyon, M.J. \& Schwalbac, J., 2000, 'Executive compensation: Evidence from the UK and Germany', Long Range Planning 33, 504-526. https://doi.org/10.1016/ S0024-6301(00)00052-2

Dabor, E. \& Adeyemi, S., 2009, 'Corporate governance and the credibility of financial statements in Nigeria', Journal of Business Systems, Governance and Ethics 4(1), 13-24, viewed 09 April 2019, from https://www.researchgate.net/profile/ Rusnah_Muhamad/publication/263969345_Religiosity_Ethical_Judgments_and Malaysian_Muslim_Students/links/02e7e53c77af28f7e5000000/ReligiosityEthical-Judgments-and-Malaysian-Muslim-Students.pdf\#page=17.

Daily, C.M., Dalton, D.R. \& Cannella, A.A., 2003, 'Corporate governance: Decades of dialogue and data', Academy of Management Review 28, 371-382. 
Dittmar, A. \& Mahrt-Smith, J., 2007, 'Corporate governance and the value of cash holdings,' Journal of Financial Economics, 83(3), 599-634. https://doi.org/ holdings,' Journal of Financial
$10.1016 /$ j.jfineco.2005.12.006

Duffhues, P. \& Kabir, R., 2008, 'Is the pay-performance relationship always positive? Evidence from the Netherlands', Journal of Multinational Financial Management 18, 45-60. https://doi.org/10.1016/j.mulfin.2007.02.004

Eichengreen, B. \& Rose, A.K., 1999, 'Contagious currency crises: Channels of conveyance', NBER Chapters, in: Changes in exchange rates in rapidly development countries: Theory, practice, and policy issues (NBER-EASE vol. 7), pp. 29-56, National Bureau of Economic Research, Inc. NBER working papers

Enobakhare, A., 2010, Corporate governance and bank performance in Nigeria viewed 09 April 2019, from https://www.scribd.com/document/221841566/ Enobakhare-Corporate-2010.

Eyong, T.O., 2001, 'Promoting good governance in the management of NGOs, Corporate Governance, 13(2), 197-210.

Festo, T. \& Nkote, I., 2013, 'Corporate governance in private universities: Financial performance perspective', Journal of Business Law and Ethics 1(1), viewed 09 April 2019, from http://jblenet.com/journals/jble/Vol_1_No_1_December 2013/1.pdf

Gavin, J.N. \& Geoffrey, G.C., 2004, 'Corporate governance, break through board performance', Journal of Public Administration and Policy Research 4(6), performance.

Gelos, R. \& Wei, S., 2002, Transparency and International investor behaviour, Working papers and publications; International Bureau of Economic Research; working papers and publications; International Bureau of Economic Resea.
paper No. 9260, viewed from https://www.nber.org/papers/w9260.

Hadi, A.R.A., Suryanto, T. \& Hussain, M.A., 2016, 'Corporate governance mechanism on the practice of International Financial Reporting Standards (IFRS) among Muslim entrepreneurs in textile industry - The case of Malaysia', International Journal of Economic Perspectives 10(2), 164-170.

Hayes, R., Pisano, G., Upton, D. \& Wheelwright, S., 2005, Operations, strategy and technology: Pursuing the competitive edge, John Wiley, New York.

Hermalin, B. \& Weisbach, M., 2010, 'The role of boards of directors in corporate governance: A conceptual framework and survey', Journal of Economic Literature $48(1), 58-107$, viewed 09 April 2019, from https://www.aeaweb.org/articles? id $=10.1257 / \mathrm{jel} .48 .1 .58$

Ho, C., 2005, 'Corporate governance and corporate competitiveness: An internationa analysis', Corporate Governance: An International Review 13(2). Wiley online library, viewed 09 April 2019, from https://onlinelibrary.wiley.com/doi/abs/ 10.1111/j.1467-8683.2005.00419.x

Hughes, O.E., 2003, Public management and administration, 3rd edn., Palgrave Macmillan, Hampshire.

Iyang, B.J., 2009, 'Nurturing corporate governance system: The emerging trends in Nigeria', Journal of Business systems 4(2), 1-13.

Jensen, M. \& Meckling, W., 1976, 'Theory of the firm: Managerial behaviour, agency costs and ownership structure', Journal of Financial Economics 3, 305-360. University of Rochester, Rochester, NY.

Jensen, M.C. \& Meckling, W.H., 1976, 'Theory of the firm: Managerial behavior agency costs and ownership structure', Journal of Financial Economics 3(4), 305-360.

Jensen, N., 2003, 'Democratic governance and multinational corporations: Political regimes and inflows of foreign direct investment', International Organization $57(3), 587-616$.

Jensen, M.C. \& Meckling, W.H., 1983, 'Organization theory and methodology', Accounting Review 50(2), 319-339.

Kairu, W., 2011, The impact of risk management on profitability of the Kenya power and lighting company staff retirement benefits scheme, University of Nairobi, viewed 09 April 2019, from http://erepository.uonbi.ac.ke/bitstream/handle/11295/12740/ Kairu_The $\% 20$ impact $\% 20$ of $\% 20$ risk $\% 20$ management $\% 20$ on $\% 20$ profitablity $\% 20$ of $\% 20$ the $\% 20$ Kenya $\% 20$ power $\% 20$ and $\% 20$ lighting $\% 20$ company $\% 20$ staff $\% 20$ retirement $\% 20$ benefits $\% 20$ scheme.pdf?sequence $=3 \&$ isAllowed $=y$

Kajola, S.O., 2008, 'Corporate governance and firm performance: The case of Nigerian listed firm', European Journal of Economics, Finance and Administrative Science, Issue 14 (2018), viewed 09 April 2019, from https://www.academia.edu/5808381/ Corporate_Governance_and_Firm_Performance_The_Case_of_Nigerian_Listed Firms.

Kakuru, J., 2000a, Financial dimensions and the business, 1st edn., Makerere University Business School, Kampala.

Kakuru, J., 2000b, Financial dimensions and the business, 2nd edn., Makerere University Business School, Kampala.

Kaplan, G.E., 2004, 'Do governance structures matter?', in W.G. Tierney \& V. Lechuga (eds.), Restructuring shared governance in higher education. New Directions in Higher Education No. 127, pp. 23-34, Jossey-Bass, San Francisco, CA.

Kaufmann, D. \& Kraay, A., 2002, 'Growth without governance: Policy research working paper 2928', The World Bank Institute and Development Research Group, viewed 09 April 2019, from https://sites.hks.harvard.edu/fs/pnorris/Acrobat/stm103\%20 articles/Kaufman $\% 20$ and\%20Kraay\%20Nov2002.pdf

Keating, E. \& Frumkin, P., 2003, 'Reengineering nonprofit financial accountability: Toward a more reliable foundation for regulation', Public Administration Review 63, 3-15. https://doi.org/10.1111/1540-6210.00260

Khan, H., 2019, A literature review of corporate governance. https://www. researchgate.net/publication/267773286_A_Literature_Review_of_Corporate_ Governance.

Kibirango, L., 1999, 'Issues on ethical conduct, ICGU', The Journal for Capital Markets Industry, Uganda 5(4) 152-185.
Klapper, L. Laeven, L. \& Love, I., 2006, 'Corporate governance provisions and firm ownership; firm-level evidence from Eastern Europe', Journal of International Money and Finance 429-444, viewed 09 April 2019, from http://siteresources. worldbank.org/DEC/Resources/Corporate_governance_provisions_and_firm ownership_Firm_level_evidence_from_Eastern_Europe.pdf.

Kolk, A. \& Pinkse, J., 2009, 'The integration of corporate governance in corporate social responsibility disclosures', Corporate Social Responsibility and Environmental Management 17(1), 15-26, Wiley Online Library. https://doi.org/10.1002/ csr.196

Kombo, D. K., \& Tromp, D. L. (2006). Proposal and thesis writing: An introduction, Paulines Publications Africa, Nairobi.

Krejcie, R.V., \& Morgan, D.W. (1970). Determining sample size for research activities, Educational and Psychological Measurement 30, 607-610.

Lan, L. \& Heracleous, L., 2010, 'Rethinking agency theory: The view from law', Academy of Management Review 35(2), 294-314.

Leuz, C. \& Verrecchia, R., 2000, 'The economic consequences of increased disclosure', Journal of Accounting Research 38, 91-124. https://doi.org/10.2307/2672910

Marshall, D., 2002, 'Behavior, belonging and belief: A theory of ritual practice', Sociology Theory 20(3), 360-380. https://doi.org/10.1111/1467-9558.00168

Matama, R., 2006, Corporate governance and financial performance of selected commercial banks in Uganda, viewed 09 April 2019, from https://www. researchgate.net/publication/238786723_.

Michaely, Roni and Rubin, Amir and Segal, Dan and Vedrashko, Alexander, Lured by the Consensus (February 22, 2018). https://doi.org/10.2139/ssrn.3128734

Munene, J. \& Mulira, F. \& Kasekende, F., 2008, 'Teacher operant competences and organisational citizenship behaviour in the performance of Ugandan primary schools', Makerere University Institute of Psychology and Faculty of Management, Makerere University Business School, Kampala. https://www.researchgate.net/publication/ 264874809_Teacher_Operant_Competences_and_Organisational_Citizenship 264874809_Teacher_Operant_Competences_and_Organisatior
Behaviour_in_the_Performance_of_Ugandan_Primary_Schools.

Munene, J.C., Bbosa, R. \& Eboyu, F., 2006, Operant competence management framework for enhancing competence management and development in organizations in Africa, Makerere Institute of Psychology, Kampala.

Ndiwalana, A., 2009, Mobile payments: A comparison between Philippine and Ugandan contexts, viewed 09 April 2019, from https://www.researchgate.net/ publication/228846415_Mobile_Payments_A_Comparison_between_Philippine_ and_Ugandan_Contexts.

Nicholson, G.J. \& Kiel, G.C., 2004, 'A framework for diagnosing board effectiveness', Corporate Governance: An International Review, Wiley Online Library, 12(4), 442-460. https://doi.org/10.1111/j.1467-8683.2004.00386.x

Parker, L.D., 2007, 'Financial and external reporting research: The broadening corporate governance challenge', Accounting \& Business Research 37(1), 39-54.

Patel, S., Balic, A. \& Bwakira, L., 2002, 'Measuring transparency and disclosure at firmlevel in emerging markets', Emerging Markets Review 3(4), 325-337.

Perkins, S.J. \& Hendry, C., 2015, 'Ordering top pay: Interpreting the signals', Journal of Management Studies, Wiley Online Library, viewed 09 April 2019, from https:// onlinelibrary.wiley.com/doi/full/10.1111/j.1467-6486.2005.00550.x

Potucek, M. et al., 2005, 'Public policy', Central European Political Studies Review 8(4), 468-469.

Reed, D., 2002, 'Corporate governance reforms in developing countries', Journal of Business Ethics 37, 223-247. http://dx.doi.org/10.1023/A:1015239924475

Robinson, M., 2003, The microfinance revolution: Sustainable finance for the poor, Communications Development Incorporated, Washington, D.C.

Sadka, R. \& Korajczyk, R., 2005, 'Are momentum profits robust to trading costs?', The Journal of American Finance 59(3), 1039-1082, http://dx.doi/org/10.1111/j. 1540-6261.2004.00656.x

Zouari, S.B.S. \& Taktak, N.B., 2014, 'Ownership structure and financial performance in Islamic banks: Does bank ownership matter?, International Journal of Islamic and Middle Eastern Finance and Management, 7(2), 146-160. https://doi.org/ 10.1108/IMEFM-01-2013-0002

Sasuni, J.O., 2003, Embracing good corporate governance practices in Nigeria, Keynote address by governor of the central Bank of Nigeria at the 19th Annual Directors seminar organized by the Financial Institutions Training Center in Abuja, Nigeria on June 17, 2003.

Schmidt, R.H. \& Tyrell, M., 2003, 'Financial systems, corporate finance and corporate governance', European Financial Management Source 3(3), 333-361. https://doi. governance, European Financial
org $1111 / 1468-036$ X.00047

Schmidt, R.H. \& Tyrell, M., 2004, Information theory and the role of intermediaries in corporate governance, Working paper series/Johann-Wolfgang-GoetheUniversität Frankfurt am Main, Fachbereich Wirtschaftswissenschaften: Finance Universität Frankfurt am Main, Fachbereich Wirtschaftswissenschaften: Finance $\& 3407$.
2340 .

Schwartz, S.H. \& Surkiss, S., 1999, 'Basic individual values, work values, and the meaning of work', Applied Psychology: An International Review 48(1), 49-71.

Slim, H., 2002, By what authority? The legitimacy and accountability of nongovernmental organizations, The International Council for Human Rights Policy, viewed 09 April 2019, from http://www.gdrc.org/ngo/accountability/by-whatauthority.html.

Smyth, R., 2004, 'Exploring the usefulness of a conceptual framework as a research tool: A researcher's reflection', Issues in Educational Research 14(2), 167-180. 
Soludo, C., 2004, Consolidating the Nigerian banking industry to meet the development challenges of the 21st century, BIS review, viewed 09 April 2019, from https:// www.bis.org/review/r040727g.pdf.

Thompson, A.A., \& Strickland, A.J., 2004, Strategic management: Concepts and cases, 13th edn., McGraw-Hill/Irwin, Boston.

Tilt, C.A., 2007, 'External stakeholders' perspectives on sustainability reporting', in J. Unerman, J. Bebbington \& B. O'Dwyer (eds.), Sustainability accounting and accountability, Routledge, New York, NY.

Wang, H., Tsui, A.S. \& Xind, K.R., 2003, 'CEO leadership behaviors, organizational performance, and employees' attitudes', The Leadership Quarterly 22(1), 92-105. https://doi.org/10.1016/j.leaqua.2010.12.009

Wanyama, S., 2006, Corporate governance and accountability in Uganda: An analysis of stakeholder perspectives, Uganda Martyrs University, viewed n.d., from https:// www.researchgate.net/publication/261720397_Corporate_Governance_and Accountability_in_Uganda_Corporate_Citizenship_in_Africa_Lessons_from_the_ Past Paths to the Future.
White, B., 2000, Dissertation skills for business and management students, Continuum Intl Pub Group, London.

Wilson, I., 2006, 'Regulatory and institutional challenges of corporate governance in nigeria post banking consolidation' Nigerian Economic Summit Group (NESG) Economic Indicators 12(2), April-June.

Wright, T.A. \& Staw, B.M., 1999, 'Affect and favorable work outcomes: Two longitudinal tests of the happy - Productive worker thesis', Journal of Organizational Behavior $20,1-23$.

Youssef, C.M. \& Luthans, F., 2007, 'Positive organizational behavior in the workplace: The impact of hope, optimism, and resilience', Management Department 7305562

Youssef, T., 2007, Corporate governance. An overview - Around the Globe (1), Principal Partner Grant Thornton, Egypt. http://www.eiod.org/uploads/Publications/Pdf/ Corp.\%20Governance-1.pdf. 